\title{
THE AXIOLOGICAL STRENGHTENING OF ETHICS IN JÓZEF TISCHNER'S THOUGHTS
}

\begin{abstract}
It seems that values dominated Tischner's thought, and the main issue that has been subject to reflection is an attempt to find the right choices from the ethical level and justification of actions. According to Tischner, values are strongly related to the human world, and moral imperatives refer only to the human world, not, for instance, to the animal world. The issue of meeting another human being is crucial in the philosophy of the Krakow philosopher because "axiological Self" has a different human being in their structure. The philosophy of Tischner is largely a result of reflection on the philosophy of dialogue.

The key purpose of this paper is a brief reflection on the world of values and ethical evaluations in the approach of Józef Tischner. The article is an attempt to approximate the basic concepts related to the ethics of the Krakow priest and philosopher. In the first part an origin of the word value, its borrowing from economic sciences and the key issues and questions related to this concept are briefly described The next part presents Tischner's definition of ethics, which is slightly wider than the traditional approach. Next the key category of experiencing values as a meeting with another man and the key issues for Tischner's: "axiological Self" and "agathological Self" were described. The article ends with a short summary and Tischner's words "nobody can be good in loneliness and no one can be necessarily good".
\end{abstract}

Keywords: values, axiological Self, agathological Self, philosophy of meeting, Józef Tischner.

\section{INTRODUCTION}

It is worth noting that fascination with the concept of value as a philosophical issue has a very short history. Philosophers in ethical considerations referred to such concepts as virtue, arete and, above all, good. The ancients successfully managed to understand the concept of values. For Socrates, knowledge that led to virtue was the highest good, and for his student Plato good was the highest idea and the first principle. Aristotle saw the good as a goal of all pursuit ${ }^{2}$. Christian medieval thinkers identified God with the highest good. Values in philosophical reflections appeared only when the goods disappeared, when they started to look at the world not from above and from the side, but from the position of another man. According to Tischner, this conversion of vertical perceptions into horizontal ones was a key to the transition from agathological ethics to axiological ethics.

${ }^{1}$ Dr Justyna Stecko, adiunkt w Katedrze Nauk Humanistycznych, Politechnika Rzeszowska, ul. Podkarpacka 1, 35-001 Rzeszów, e-mail: jstecko@prz.edu.pl Justyna Stecko, PhD, Assistant Professor, Rzeszów University of Technology, Faculty of Management, Department of Humanities, ul. Podkarpacka 1, 35-001 Rzeszów, e-mail: jstecko@ prz.edu.pl ${ }^{2}$ V.J. Bourke, Historia etyki, wydawnictwo Krupski i S-ka, Toruń 1994, p. 25-45. 
It was not until modern times that the concept of values was used in philosophical sciences, but it was not its source. Value is a key economic concept as the correctly definition of the value of services or goods was extremely important to achieve the assumed financial results and the right market strategy. In the literature one can find definitions of a market or production value, because the valuation of goods was specified not only on the basis of costs incurred, but above all, on the basis of a subjective assessment. Transfer from economic sciences to philosophy took place only in the nineteenth century and turned out to be extremely creative. The philosophical problem of values is a multi-faceted problem. Numerous works concern the variability of values depending on time and circumstances, sources of value, the way they are learned, autonomy or even their basic hierarchy. Numerous disputes indicate not only an interest in this concept but also an ambiguity of this issue. In the texts of Józef Tischner, we will not find an answer to all these questions, but the key seems to be able to be answered.

\section{IS "A MAN INHERENTLY AN ETHICAL BEING"?}

In the texts of Józef Tischner, we can find sources of inspiration with many philosophers. However, Martin Heidegger may be the key to this study. Both a definition of ethos and an issue of values were inspiring. Tischner, inspired by Heidegger, definitely modifies a traditional approach to ethics as a science of morality. In the Letters on Humanism by Heidegger, whose translator was Tischner, one can find the category of ethos which, in the author's opinion, "means a stay, a place of residence (...) it is the name for an open area where a man lives. The open space of his residence allows him manifesting himself in what is approaching the essence of a man, and what comes to pass, stays in its vicinity (...) Ethics reflects on the human's stay"3. According to Tischner, ethics also applies to the place, the environment where a person lives and meets with others. Tischner extended this concept to the whole of human experience. "A man, to live, to develop and to be himself, also needs ethos. It is produced not only by air, land and water, but above all by the human environment, other people. (...) A man is inherently an ethical being, i.e. someone for whom the problem of ethos is also a problem of one's being. If he finds out where, among what matters, what kind of people his ethos is associated with, he can "bear fruit abundantly". If he does not find it, he will live as a being alien to himself" ${ }^{4}$. According to Tischner, " $(. .$.$) the$ main task of ethics is to accompany a man on the path of his life and show as clearly as possible the values his fate is revolving around" . According to Tischner, properly practiced ethics should "result in an internal order in man". Ethics should not be pure science because different experiences are inspiration. Its purpose is to clarify human responsibility, a source of human unrest, the scope of human freedom, and the justification of specific choices. The concept of the Krakow philosopher is rather a philosophy of a man who moves us to axiology in small steps.

\footnotetext{
${ }^{3}$ M. Heidegger, List o humanizmie [in:] Budować, mieszkać, myśleć. Eseje wybrane, tłum. J. Tischner, Warszawa 1977, p. 119.

${ }^{4}$ J. Tischner, Etyka wartości i nadziei [in:] D. von Hildebrand, J.A. Kłoczowski OP, J. Paściak OP, Wobec wartości, Poznań 1982, p. 53.

5 J. Tischner, Etyka Solidarności oraz homo sovieticus, Kraków 2005, p. 17.
} 


\section{THE ISSUE OF A VALUE}

From the moment when a man began to be aware of his own existence, he is constantly struggling with the experience of values. However, the world of axiology is not simple, it is not black - white, nor zero - one. The number of choices that accompanies human activities is innumerable. Unfortunately, most often we do not choose between a clearly defined good and evil. We often encounter a category of lesser or greater evil or good. According to Gołaszewska, “... there is a common conviction that there is a lesser evil and a greater evil, that certain human behaviors, as well as states of affairs, can be ranked due to the moment of their relationship with certain values - negative and positive ones" 6 . Gołaszewska also refers to an interesting chess comparison to approximate the problem and the amount of "axiological combinations"7.

The Heidegger's concept of values seems to be the key of Tischner's inspiration: "Thinking according to values is here and everywhere the greatest blasphemy against being that one can think of. So thinking against values does not mean: to beat a drum in honor of worthlessness and vanity of being. It means to put a clear view of the truth of being before thinking despite the subjectivisation of being which makes it only an object"8.

A few years after translating this text, Tischner published a book entitled "Thinking according to values". In this text a very interesting hierarchy metaphor can be found: "We are in the lecture hall at the moment. There are friends and strangers next to us, professors and colleagues, people more or less nice, there are also items such as chairs, windows, doors, there are instruments to strengthen the voice. Every human being and every subject requires us to receive an appropriate recognition and an appropriate behavior. In order to behave properly in this small world, we need to be able to read values. We do not welcome our chairs, we do not try to look for a place for ourselves on the laps of people already sitting. Without the necessary need, we do not sit back to the podium. Our present world is

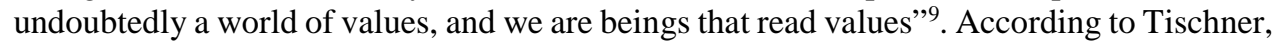
"a man lives in the midst of values towards which his aspirations, thoughts and deeds are guided"10, while ethics is nothing but the science of values ${ }^{11}$. Tischner's thoughts evolved and changed, therefore it is necessary to judge judgments about values and their experience, but the key and unchangeable in the concept of the Krakow philosopher was to meet another man. From the end of the 1970s Tischner appreciated the philosophy of dialogue more and more because it is the "other" and the "second" that opens the perspective of values, the encounter with the other is at the beginning of experiencing of the world. One can say that the second is an a priori category. Thanks to this the so-called objective world is possible. It is "the experience of another person that means opening to me the ethical horizon of my existence"12. In another place he writes: "the original source of ethical experience is not the survival of values as such but the discovery that a second person has appeared next to us"13.

${ }^{6}$ M. Gołaszewska, Fascynacja złem. Eseje z teorii wartości, Warszawa-Kraków 1994, p. 70.

7 Compare: J. Stecko, Applied ethics, i.e. the issue of norms and values in the choices of everyday life, Logos and Ethos 2018 [in print].

${ }^{8}$ M. Heidegger, List..., s. 300.

9 J. Tischner, Myślenie wedtug wartości, Kraków 1982, p. 483.

${ }^{10}$ J. Tischner, Etyka wartości i nadziei..., p. 54.

11 Ibidem.

12 J. Tischner, Myślenie wedtug..., p. 399.

13 J. Tischner, Etyka wartości i nadziei..., p. 85. 
According to Tischner, "neither values, nor norms, nor even commandments are first, but the presence of another person"14. Only this creates the horizon of values. The source experience for human ethical self-knowledge is the experience of the other $\operatorname{man}^{15}$. In this experience one finds their foundations ethical values: truth, justice, faithfulness etc. ${ }^{16}$. Here the basis of objectivity for our ethical commitments and the source of real responsibility (...) lies"17. Tischner's ethics is based on the available experience, but it is important, while meeting with another man, to take into consideration all beliefs, reject judgment as it is a kind of and transcendental reduction, an epoche. "This reflection assumes nothing more than the fact that ethical situations exist"18. Tischner, like Hartmann, believes that ethics is able to awaken a man to a more conscious experience of his moral choices while developing his ethical sensitivity. Tischner believed that "a man cannot be a being of a radically evil will. Even when he does evil, he seeks some good in it"19. I would not like to call this concept naive, but it seems that there is a noticeable ambiguity. Of course, you can look at the life of a man in the Augustinian way and look for good in the worst experiences, but this concept is directed only to the believers, and in addition can raise a lot of doubts.

\section{AXILOGICAL AWARENESS}

Moral awareness is a kind of axiological consciousness which is our sensitivity to any value. So it is an ability that estimates responsibility for the good or evil that we have done to another human being. It is a certain attribute that accompanies a man. The axiological consciousness, due to its phenomenological origin, is based mainly on qualitative methods and will be realized more as an anthology of contributions than a hard theory ${ }^{20}$. "The dimension of humanity opens in man thanks to the feeling of the" axiological Self "and associated with this feeling of experiencing the external world in its axiological dimension" 21. According to Tischner the experience of "the axiological Self" is a condition that animates all those structures and models how a man was perceived by Husserl, Heidegger or even Ricoeur. ${ }^{22}$. "Axiological Self" shows a man who is always a value, and an attempt to penetrate himself is also a kind of discovering the ethical plane.

Each of us is first and foremost a value for ourselves. "My Self is the axiological Self. However, this value only reveals when it serves different values. Tell me for what values you sacrifice, and I will tell you how much you value yourself. The axiological artist's Self is revealed in works of art. The axiological Self of a religious man is revealed in a prayer and good deeds. The axiological Self of a man of science is revealed in his scientific works. Each one carries a score of values according to which he plays his life" ${ }^{23}$.

\footnotetext{
14 Ibidem.

15 J. Tischner, Myślenie wedtug..., p. 399.

${ }^{16}$ Ibidem.

17 Ibidem.

18 J. Tischner, Wartości etyczne i ich poznanie, Ref. no. 215/1972, p. 630.

19 J. Tischner, Myślenie wedtug..., p. 400.

${ }^{20}$ Por. J. Stecko, Applied ethics...

21 J. Tischner, Świat ludzkiej nadziei, Kraków 2005, p. 123.

22 Ibidem, p. 122.

${ }^{23}$ J. Tischner, Drogi i bezdroża miłosierdzia, Kraków 1999, 59.
} 
Tischner often said that "it's enough to do little to change a lot" and he simply said that there was nothing simpler than "do not kill", "do not lie", "betray" and people still lie, betray and kill, additionally rationalizing that it should be done so. A modern man easily justifies his immorality and indifference to evil with the phrase repeated so often that "everyone does it" 24 .

"Axiological Self" is the basic condition to experience values and axiological hunger can be saturated during the realization of values. The axiological Self is the center of participation in good. Interestingly, the phrase from the concept of value to the notion of good, from the axiological plane to the agathological plane is noticeable in Tischner's thought. To exist realistically, wrote a Krakow thinker, means to give a birth to good, whereas a man "exists more" when he becomes "better". The axiological Self appears to be an ability to choose good, it is a kind of core of self-awareness, by means of which a man distinguishes good from evil and chooses the first. According to Tischner, it is a value of a special type, while the self-awareness of this "Self" is colored egotically (that it is just me) and axiologically (that it is a specific value) ${ }^{25}$.

Tischner noticed a certain relation: "whoever obtained the title of a doctor of medicine, a wide perspective of axiological activities was revealed, which remains closed to others. On the other hand, he is accompanied by the awareness of irrevocable slamming of other axiological horizons and irreversible impoverishment. The poet, who became a doctor, lost something from the poet and did not achieve anything from the doctor" ${ }^{26}$. It turns out that by choosing one option, we abandon another; choosing one value, we abandon another. The man by Tischner is a being that "is in a state of constant becoming ${ }^{27}$ ", we cannot even say that he is because he is constantly evolving. "A man brings through life his axiological Self - the Self understood as a value. He is what this value is. Despite the flaws and limitations, he seems to be irreplaceable, valuable and worthy of absolute recognition.

A man is the absolute for himself in his axiological Self. However, this is a strange absolute because it is not enough for himself. From the bottom of his heart, he demands absolute recognition from another person" ${ }^{28}$. Tischner pushed the ontological issues to the background and focused on the issue to commune with respect to values and to good. "Good requires from me to give bread to the hungry. Even if it is an illusion, it does not follow that I should not give bread to the hungry - and therefore the existence or non-existence of such a being as the Good does not affect my behavior towards another person in any other way" 29 . The agathological experience is above all a revealing experience, and an axiological experience is an experience that design, develops. The agathological experience concerns being in the light of good, axiological experience concerns events in the light of what is valuable ${ }^{30}$. In the book "Controversy over the existence of man", Tischner wrote: "objectification in value is a threat to discovering the dimension of participation in good. For a long time,

\footnotetext{
${ }^{24}$ J. Stecko, „Wystarczy zrobić niewiele by zmienito się wiele”, czyli czym jest etyka solidarności [in print].

25 J. Tischner, Świat ludzkiej..., p. 217.

${ }^{26}$ Ibidem, p. 165.

27 J. Tischner, Spór o istnienie człowieka, Kraków 2000, p. 9.

28 J. Tischner, Ksiądz na manowcach, Kraków 1999, p. 15.

29 J. Tischner, Uprawiam filozofię Dobra [in:] Rozmowy o filozofii, red. A. Zieliński, M. Bagiński, J. Wojtysiak, Lublin 1996, p. 261.

${ }^{30}$ J. Tischner, Myślenie..., p. 490.
} 
philosophers have been trying to replace the notion of good with the concept of value. In this way one attempts to bring good to the phenomenological experience. However, has this goal been achieved? In fact, what is achieved is the aesthetization of good: good brought into a value becomes an aesthetic value" ${ }^{31}$.

\section{CONCLUSION}

When reading Tischner's texts, one canot resist the temptation to compare them to authors such as Edmund Husserl, Max Scheler, Nicolai Hartmann, Dietrich von Hildebrand, Roman Ingarden and Hans Reiner, but also the less obvious Sigmund Freud and ancient thinkers. However, this does not diminish in any way the magnitude of his thoughts. Józef Tischner paid special attention to the world of values, which is the plane of constant choosing, putting one good over other good, choosing the greater good and lesser evil. At this point one can see some convergence with Gołaszewska's proposal, who pointed to the checkerboard of values and axiological possibilities ${ }^{32}$. However, what seems to be the most important in Tischner's concept, especially in the face of contemporary discussions about helping others, is to pay attention to the importance of meeting and relationships with other people. Human axiological paths intersect, which affects the condition of a human being wandering around them. As Tischner remarked: "no one can be good in loneliness and no one can be necessarily good"33.

\section{REFERENCES}

1. Bourke V.J., Historia etyki, wydawnictwo Krupski i S-ka, Toruń 1994.

2. Gołaszewska M., Fascynacja złem. Eseje z teorii wartości, Warszawa-Kraków 1994.

3. Heidegger M., List o humanizmie [in:] Budować, mieszkać, myśleć. Eseje wybrane, tłum. J. Tischner, Warszawa 1977.

4. Stecko J., Applied ethics, i.e. the issue of norms and values in the choices of everyday life, Logos and Ethos 2018 [in print].

5. Stecko J., Wystarczy zrobić niewiele by zmieniło się wiele” czyli czym jest etyka solidarności [in print].

6. Tischner J., Etyka Solidarności oraz homo sovieticus, Kraków 2005.

7. Tischner J., Etyka wartości i nadziei [in:] D. von Hildebrand, J.A. Kłoczowski OP, J. Paściak OP, Wobec wartości. Poznań 1982.

8. Tischner J., Drogi i bezdroża miłosierdzia, Kraków 1999.

9. Tischner J., Ksiądz na manowcach, Kraków 1999.

10. Tischner J., Myślenie wedtug wartości, Kraków 1982.

11. Tischner J., Spór o istnienie człowieka, Kraków 2000.

12. Tischner J., Świat ludzkiej nadziei, Kraków 2005.

13. Tischner J., Uprawiam filozofię Dobra [in:] Rozmowy o filozofii, red. A. Zieliński, M. Bagiński, J. Wojtysiak, Lublin 1996.

14. Tischner J., Wartości etyczne i ich poznanie, Ref. no. 215/1972.

\footnotetext{
31 J. Tischner, Spór o istnienie..., p. 177.

${ }^{32}$ M. Gołaszewska, Fascynacja ztem...

${ }^{33}$ J. Tischner, Myślenie..., p. 343.
} 


\section{AKSJOLOGICZNE UGRUNTOWANIE ETYKI W MYŚLI JÓZEFA TISCHNERA}

Wydaje się, że problematyka wartości zdominowała myśl Józefa Tischnera, a główne zagadnienia, które zostały poddane refleksji to próba odnalezienia właściwych wyborów z perspektywy płaszczyzny etycznej oraz uzasadniania działań. Zdaniem Tischnera wartości są mocno związane z ludzkim światem, a imperatywy moralne odnoszą jedynie do świata ludzi, nie zaś na przykład do świata zwierząt. To co kluczowe w filozofii krakowskiego filozofa to zagadnienie spotkania z drugim człowiekiem, ponieważ „Ja aksjologiczne” w swoją strukturę ma wpisane drugiego człowieka. Filozofia Tischnera w dużej mierze jest efektem refleksji nad filozofią dialogu.

Kluczowym celem tego opracowania to krótki namysł nad światem wartości i ocen etycznych w ujęciu Józefa Tischnera. Artykuł jest próbą przybliżenia podstawowych pojęć związanych z etyką krakowskiego księdza i filozofa. Opracowanie w pierwszej części pobieżnie opisuje pochodzenia słowa wartość, jego zapożyczenie z nauk ekonomicznych oraz kluczowe zagadnienia i pytania związane z tym pojęciem. W kolejnej części przybliżono tischnerowską definicję etyki, która jest nieco szersza niż ujęcie tradycyjne, dalej zaś opisano kluczową dla tego opracowania kategorię przeżycia wartości, jako spotkania z drugim człowiekiem oraz kluczowe dla Tischnera zagadnienia jak: ,,ja aksjologiczne” oraz ,ja agatologiczne”. Artykuł kończy krótkie podsumowanie i słowa Tischnera „nikt nie może być dobry w samotności i nikt nie może być dobry z konieczności”.

Słowa kluczowe: wartości, ja aksjologiczne, ja agatologiczne, filozofia spotkania, Józef Tischner.

DOI: $10.7862 /$ rz.2018.hss.33

Przestano do redakcji: kwiecień $2018 \mathrm{r}$.

Przyjęto do druku: czerwiec 2018 r. 
